v. $11, n .6$

Vitória-ES, Nov.-Dec. 2014

p. $98-122 \quad$ ISSN 1808-2386 DOI: http://dx.doi.org/10.15728/bbr.2014.11.6.5

\title{
Developing an Evaluating System to Improve Efficiency, Effectiveness and Governance in the Public Sector: the Case of the Program of Subsidies to Exporting Companies in Brazil
}

\author{
Frederico Lustosa da Costa \\ Universidade Federal Fluminense - UFF \\ José Cezar Castanhar ${ }^{\Omega}$ \\ Fundação Getúlio Vargas - FGV \\ Daniela Gomes Castanhar Reyes ${ }^{¥}$ \\ Faculdade IBMEC \\ Gustavo de Oliveira Almeida ${ }^{ \pm}$ \\ Fundação Getúlio Vargas - FGV
}

\begin{abstract}
Improving a country's export is widely acknowledged as a strategic issue. For a developing country, the benefits are multiple: expand the markets for goods and services to a global scale contributing to job creation, set technological and management standards for the sectors of the economy and reduce the country's external vulnerabilities by generating reserves. Those benefits justify the adoption of public policies to support and foster exports, but it is essential to ensure that the resources invested in these programs are being effectively used, requiring the design and implementation of evaluation systems. This article aims to present and discuss an evaluation model for PROEX, Brazilian Program for Supporting Exports. The model proposed include definition and calculation of a set of indicators that will allow the monitoring of the extent to which the program is achieving its main objectives. We believe that the evaluation model proposed will help to improve the efficiency, effectiveness and governance of the Program.
\end{abstract}

Keywords: Public policy. PROEX. Evaluation. Exports.

Received on March 31, 2013; reviewed on November 04, 2013; accepted on November 13, 2013 ; disclosed on November $27,2014$.

*Autor para correspondência:

${ }^{\dagger}$. Doctor in Management by Instituto Universitário de Lisboa (ISCTE/IUL)

Institution: Professor of

Programa de Pós-graduação em Administração da Universidade Federal Fluminense (UFF). Address: Rua Nascimento Silva, 32, apto 101 - Ipanema. Rio de Janeiro - RJ - Brazil

E-mail:

fredericolustosa@id.uff.br

Telephone: (21) 2629-9867

\author{
${ }^{\Omega}$ Doctor in Management by \\ Instituto Universitário de \\ Lisboa (ISCTE-IUL) \\ Institution: Professor of \\ Fundação Getulio Vargas \\ (FGV). \\ Address: Rua Tonelero, no \\ .43 , Ap. 803, Rio de \\ Janeiro - RJ - Brazil \\ E-mail: castanhar@fgv.br \\ Telephone: (21) 37994513
}

${ }^{¥}$ Master in Management by
Faculdade IBMEC
Address: Rua Otaviano
Hudson, Rio de Janeiro -
RJ - Brazil - E-mail:
dcastanhar@ globo.com
Telephone: (21) 2542-7550

\author{
† Doctor in Management by \\ Escola Brasileira de \\ Administração Pública e de \\ Empresas da Fundação Getúlio \\ Vargas \\ Institution: Researcher in \\ EBAPE/Fundação Getúlio \\ Vargas, Pesquisador do Núcleo \\ de Estudos de Avaliação de \\ Políticas e Programas Públicos \\ (NEAPP) do Programa de Pós- \\ graduação em Administração \\ (PPGAd) da UFF \\ Address: Praia de Botafogo - \\ Rio de Janeiro - RJ - Brazil \\ E-mail: goalmeida@gmail.com \\ Telephone: (24) 98100-2322
}




\section{INTRODUCTION}

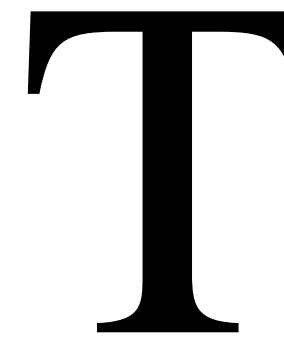

he performance of a country's exports is widely acknowledged as a strategic issue. Improving exports is equivalent to expand the markets for a country's products and services to a global scale and therefore yielding important contributions to economic growth and job creation (TYLER, 1981; FEINBERG, 1982; KAVOUSI, 1984 NEVEN; SEABRIGHT, 1995; HARRIES, 1998; HARRISON; RODRÌGUEZ-CLARE, 2009).

Empirical data shows that firms that export have better performance than their counterparts that only do business domestically (MELITZ, 2008). For instance, Taylor (1994) found that exporting firms grew up twice as fast in sales and also had higher returns on equities and assets. Other studies found that they also pay significantly better wages (BERNARD; JENSEN, 1995; SCHANK; SCHNABEL; WAGNER, 2007), are more productive and innovative (CASSIMAN; GOLOVKO; MARTÍNEZ-ROS, 2010), and in general are more stable than firms that do not export (RICHARDSON; RINDAL, 1996).

The increase of exports allow a robust surplus on the trade balance, that tends to reduce the emerging countries' external vulnerabilities ${ }^{1}$, allowing them to face international shocks with less damage for the economy. This is why developed and emerging countries alike have, since long designed governmental policies to support the country's exports (LALL, 1997; HARRISON; RODRİGUEZ-CLARE, 2009; GILES; WILLIAMS, 2000). Those policies include the creation of institutions or programs to provide funds to finance exports, to finance the exports directly or to back the risk of the buyer's country (BELOC; DI MAIO, 2011).

The Brazilian export financing program - PROEX - is one of such policies. The program is strategic to the country for many reasons. First, Brazilian exports performance has an important effect on reducing the country's external vulnerability. This was demonstrated over the last years, while the country dealt with serious external shocks that had little or no impact over domestic economy, in comparison with similar situations in previous years (especially until 2002). To some extent, the Brazilian economy resilience to external shocks has been associated to significant trade balance surpluses generated since 2003, which resulted primarily from a robust and consistent increase of Brazilian exports in the last years (from 2002 to 2008 the exports grew from US\$ 60 billion to US\$ 242 billion (BCB, 2013).

\footnotetext{
${ }^{1}$ According to IMF (Debt- and Reserve-Related Indicators of External Vulnerability, IMF (2005) Important indicators of the external vulnerability of the financial sector are gross external liabilities, open foreign currency positions (if significant), and indicators of the maturity and quality mismatch in the foreign currency position that include off balance sheet items such as derivatives.
} 
Second, to compete in foreign markets, companies need to improve their management standards and to continuously invest in technological innovations, and some of these improvements will even spill over to sectors and companies that are not directly related to the external sector (BLOMSTRÖM; KOKKO, 1998).

Third, it is widely recognized that the excellent performance of Brazilian external sector worked as a safety net for the economy, avoiding decrease in 2002/2003 crisis that followed the presidential election, as well as played an important role when the country resumed growth, after 2003. Fourth, the reduction of the external vulnerabilities and the resume of economic growth are usually followed by the increasing of foreign direct investment, which helps the strengthening of balance of payments and work as an additional stimulus to improve growth.

Although PROEX may be important to the performance of economy, it uses public funds, being mandatory to ensure that the funds invested in the Program are used effectively and with transparency. This objective is very important in developing countries, which deals constantly with a scarcity of resources and has the need to attend an increasing and complex array of demands, especially in terms of social policies.

Thus, to ensure that the public funds invested in the PROEX are used efficiently, effectively and with transparency is an important and urgent task, due to the increasing social pressure for accountability of the use of public funds, frequently through the use of egovernment initiatives, especially in developed countries (UN, 2012). This is the goal of the present paper, organized in four sections.

In the following section we will briefly present the international trade practices and regulations and a brief review of Brazilian policies in this matter. The third section presents a detailed presentation of the PROEX, its operational characteristics and some information on the program results, and previous evaluation. Fourth section discuss the analytical framework for evaluating public programs and present a model to provide a systematic evaluation of the program, and a methodology to enhance the application of the equalization of interest rates, improving its transparency and governance. The fifth section presents the final remarks and conclusions. 


\section{AN OVERVIEW OF POLICIES AND REGULATIONS FOR INTERNATIONAL TRADE}

\subsection{INTERNATIONAL PRACTICES AND REGULATIONS}

The expansion of exports is one of the highest priorities of governments worldwide, for both developed and developing countries. According to a comprehensive empirical literature, exports are considered one of the major drivers for economy growth (Harrison and RodrìguezClare, 2009; Giles and Williams, 2000). Also the government may intervene with the objective to choose the sectors in which the country should specialize (LALL, 1997; AN; IYIGUN, 2004; HAUSMANN et al., 2007).

To attain such objectives, policies and practices known as Export Promotion Practices (EPP) have been conducted by the majority of the countries to enhance their exports (LALL, 1997; BELOC; DI MAIO, 2011). OECD defines EPPs as the set of 'specific measures that generally amount to the government bearing a portion of the private cost of production of export' (OECD, 1984).

Beloc and Di Maio (2011) point out that in general EPPs encompass all the measures and programs to aid current and potential exporters in foreign markets penetration, with instruments such as export subsidies, reduced tax rates to exporting firms' earnings, favorable insurance rates, advantageous financial conditions, or variations in the exchange rates. Export promotion activity is nowadays widespread and most governments intervene in one way or another, with policies ranging from providing infrastructure support to offering direct export subsidies (BELOC; DI MAIO, 2011).

Studies from the Organization for Economic Cooperation and Development (OECD, 2005) gather a broad array of evidence that financing, subsidies and guarantee mechanisms directed to international trade are widely adopted. In this study the OECD summarized the mechanisms and instruments adopted by 34 countries. All countries surveyed had some sort of system to ensure the political risk of the buyers. Most of them also cover the commercial risk and some of them offer reinsurance to private institutions.

Therefore, supporting exports is a very common practice. Even developed countries have their EPPs, sometimes even subsidizing interest rates (FEINBERG, 1982; HARRIES, 1998). Nevertheless, usually those countries do not allow a final interest rate lower than the one established by OECD: CIRR (Commercial Interest Reference Rate). Governments maintain specific agencies called Export Credit Agencies (ECA) to supply credit for exports. 
ECAs can be organized in many ways: governmental agency, independent agency, publicprivate firm or even a private institution operating in accordance to the government.

Since the creation of the World Trade Organization (WTO), there is a tendency towards more transparency in the mechanisms to support international trade from all countries, no matter which structure is adopted. Although governments have largely used trade policies to influence export flows, the use of selective export subsidies is currently severely limited by the WTO rules (BELOC; DIMAIO, 2011). Beloc and Dimaio (2011) also affirm that WTO rules allow the use of trade policy interventions in the form of selective subsidies to promote (a) domestic investment in research and development, (b) regional development, (c) environment friendly activities.

For the countries that are members of the WTO, the failure to comply with the trade regulations is considered a liability that can lead to suing and, eventually to penalties and fines. In fact, a few years ago Brazil was involved in a commercial dispute at WTO - World Trade Organization - with Canada that complained about subsidized aircraft exports. In 2007, Brazil signed an agreement with OECD country members that establishes the export credit aspects of this sector. Thus, the governance of the country's policies should ensure that it will not create liabilities before international regulators.

\subsection{THE BRAZILIAN POLICIES AND INSTRUMENTS TO FINANCE AND SUPPORT EXPORTS: A HISTORICAL OVERVIEW}

The public policies created to support Brazilian exports followed two distinctive stages: before and after the trade liberalization that was implemented in the 1990s in the administration of President Fernando Collor. Veiga and Iglesias (2003) characterized the first stage, from 1964 to 1990, as a centralized model with strong use of subsidies and regular devaluation of the Brazilian currency. In the second stage, after 1990, a more complex and integrated public system directed to support Brazilian exports was created.

It is important to mention that the first stage of public policies to support exports represented a radical change in the country's strategy toward economic development, which existed for decades. In fact, the wave of economic growth that Brazil experienced in the 1950s was based upon the "imports substitution" model, inspired by CEPAL (PREBISCH, 1949). According to this model, adopted in many other Latin American Countries, the economic development would require the creation of an integrated industrial sector, and that industrialization should be fostered through the domestic production of goods previously 

imported, hence "import substitution" (TAVARES, 1963). The international trade policies then, emphasized the protection of the local industry sectors through trade barriers and tariffs.

Therefore, in the late 1960's and 1970's, although the restrictions to imports were persistent, the focus of the trade policies changed to support Brazilian exports with an emphasis on manufactured goods. The policies were needed to promote growth and development of the economy. In the period comprising 1962 to 1967 the country underwent an economic stagnation. Although the real GDP growth rate had reached $10.3 \%$ in 1961 it had diminished to $2.4 \%$ in 1964 , and the balance of payments was not in a good situation due to poor export performance and low level of both public and private inflows (BAER, 1973).

The policies embraced reductions on tax burden for exports, simplification of administrative procedures for exporters, a number of tax incentives to increase imports were introduced, along with the reduction of tax on imported goods used as inputs to exports (a strategy known as "draw back") as well as an aggressive use of tax and credit subsidies (BAER, 1973). The implementation of these policies was heavily dependent on public funds. Although not solely affected by export sector performance, the governmental policies seem to have been effective, in the the period 1968-72 the country's real GDP has grown at average annual rates of 10 per cent (BAER, 1973). The flow of international trade reached another threshold in this period, breaking the US\$ 10 billion of annual exports in the second half of 1970s.

In the 1980s years Brazil and other developing countries faced two simultaneous threats: a fiscal crisis in the public sector that followed an imbalance between declining fiscal revenues and growing public expenditures, and the external debt crisis that followed the Mexico default in 1982, which interrupted the flow of international funds to the country. The priority to fiscal adjustment, at the time, made difficult to implement any kind of policy to support exports that demanded fiscal subsidies. All these factors resulted on the discontinuity of the prevailing exports promotion model. To compensate the interruption of foreign investments and loans and to restore the equilibrium in the country's Balance of Payment, the policies turned, once again, to a strict control of imports to allow the generation of significant trade surpluses. In fact, the volume of imports fell from US\$ 23 billion in 1980 to an average of US\$ 14.4 billion between 1983 and 1988. The average trade surplus in this period was US\$ 11.8 billion (BCB, 2012), which allowed the country to face and overcome the shortage of international funds that followed the default in 1983. 
As the flow of international capitals to emerging countries normalized in the beginning of 1990s, the governmental policies to support Brazilian exports were resumed, but within a different framework, defined before as the second stage. Under this new framework, the policies would emphasize the use of "non-budgetary" public funds to finance exports, and even so, only as a complement of private funds. In this period, the exports approached the level of US\$ 50 billion (BCB, 2013).

The budgetary resources were to be used primarily to compensate the higher cost of funds to Brazilian companies, influenced by the high "country risk" spread, a mechanism known as "equalization of the interest rate". In fact, in 1990 the BNDES (Brazil National Social and Development Bank) EXIM (Export-Import) Funds was created, and in 1991 the PROEX program was established. A compact timeline of the events is presented below:

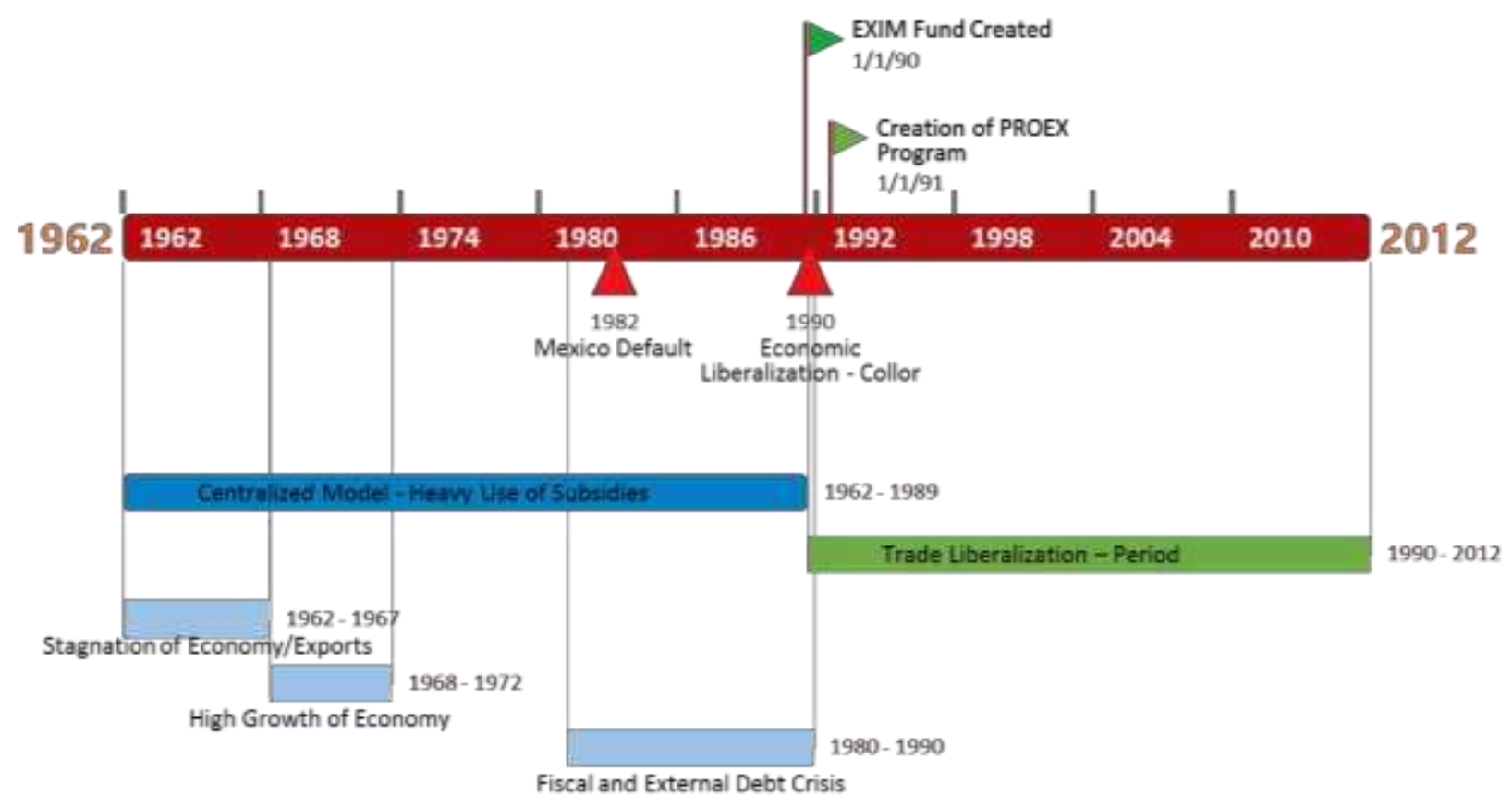

Figure 1 - Timeline of events.

\section{PROEX: CHARACTERISTICS, ANTECEDENTS AND PRESENT SITUATION}

The PROEX is one of the main official mechanisms to support Brazilian exports. The program has two different instruments: export financing and equalization of interest rate. The funds for both mechanisms are defined every year in the Governmental Budget under the account Official Credit Operations.

In the financing mode, the Treasury Department offers funds to finance loans to Brazilian firms' exports. Banco do Brasil is the program manager and the agent of its operations in the financing mode. In the equalization mode, the Treasury

Department 
compensates foreign operations costs by granting to the financing agent (usually a private bank) a subsidy to reduce the final loan rate, in order to make it comparable to international rates. The equalization is granted through bond issuing (NTN-I: Treasury Department Bond, I Series) and represents a credit subsidy. The program regulation allows financial and credit institutions in Brazil and abroad, other than the official banks, to operate this instrument.

The rationale of the PROEX instruments answers to different objectives. Thus, the export financing mechanism intents to complement the supply of private funds, offering more competitive conditions in terms of interest rates, especially to industry sectors considered strategically priorities. As for the equalization of interest rate mechanism, the goal is to bring the final cost of funds used by Brazilian exporting companies to levels comparable to international standards. This is a crucial problem for Brazilian companies, since the final cost of the loans are increased by the Brazilian "country risk". Since the Brazilian country risk, as in many other developing countries, is usually very high, volatile, and eventually distorted, the lack of an equalization mechanism would compromise the competitiveness of Brazilian exports in the global markets.

\subsection{LEGAL AND OPERATIONAL ASPECTS}

The following criteria are considered to set PROEX equalization operations: 1) up to $85 \%$ of the exports proceeds are entitled to equalization. 2) the maximum loan period to benefit from the equalization is defined by product type; and 3) the maximum equalization spread allowed is $2.5 \%$ p.a. (250 basis point per annum), depending on the period of financing. Besides these conditions, for the aircraft sector, the minimum rate after equalization should be equal to OECD rate (CIRR).

In the last 11 years the Brazilian country risk experienced a significant improvement, falling from 700 basis points (which mean 7\% per annum over the US Treasuries) in 2001 to approximately 180 points in April of 2012 (BCB, 2012). Country risk is a concept that aims to express, in an objective manner, the risk of credit that foreign investors are exposed when they invest in a given country $(\mathrm{BCB}, 2012)$. That reduction followed a general improvement of the Brazilian macroeconomic conditions in the period, especially related the external vulnerabilities. In this period the Brazilian exports grew from US\$ 50 billion to US\$ 256 billion in 2011, the governmental external debt was paid off and the country's reserves in hard currencies reached more than US\$ 370 billion by May, 2012 (BCB, 2012).

As a consequence of country risk reduction, the cost of funds for Brazilian companies also experienced a significant reduction. Despite the improvement in the country risk, the 
maximum equalization spreads allowed by PROEX regulation are the same since 1999 (250 basis points). Therefore, market conditions, represented by the external financing cost, and the granted subsidy are not aligned. For instance, eleven years ago, the funds for Brazilian firms could cost $10 \%$ per annum, in dollars term. This was the result of the international rate (Libor) plus the Brazilian Country Risk (700 basis point at the time). So, an equalization subsidy of $2.5 \%$ would reduce the final cost to $7.5 \%$ per annum, which would still be a cost significantly high. Currently, Brazilian firms could raise money in the international market at 5\% per annum (corresponding to the currently Libor rate plus a country risk of approximately 200 basis point). In this scenario, a subsidy of $2.5 \%$ (250 basis points) would lower the final cost to $2.5 \%$ per annum, which is lower than the market conditions, even for companies from developed countries.

That subsidy puts Brazilian companies in a convenient condition to compete in the international market, but might raise problems. It can lead to legal liabilities to Brazil with organizations, such as the WTO. In addition, it represents a fiscal burden that is shared by the society as a whole, while resources could be applied in issues that may be more urgent.

Consequently, an alternative for a new equalization methodology for export operations would be simply reviewing the maximum spreads allowed. A technical analysis of the country risk reduction impact on the exports financing costs for Brazilian firms over the last 7 years would determine the level of spread reduction recommended. However, this is not purely a technical matter. Then, in the following sections an equalization methodology that considers other relevant aspects regarding export financing will be suggested.

\subsection{SOME STYLIZED FACTS ON PROEX RECENT PERFORMANCE}

PROEX is a program created to support the exports for strategic sectors of the economy using either financing or equalization mechanisms. In 2011, most exports that used equalization mechanism were composed of machines and equipment (72\%), followed by transports (20\%) and services (8\%).

The funds of equalization mechanism were virtually exclusive to large companies, $96 \%$ of funds, and $99 \%$ of operations in 2011 were assigned to large companies, although the small and medium firms comprise $26 \%$ of the companied benefited $(n=7)$. Most exporters were based in Sao Paulo State (60\%), Minas Gerais and Santa Catarina were tied in the second position (12\% each) (MDIC,2011). 
In comparison, the financing mechanism in the same year was used mostly to support agribusiness (58\%), and textiles and leather products (24\%) exports. The funds were more evenly distributed between companies of different sizes than in equalization mechanism. Large companies received $47 \%$ of the funds; medium firms (300 to 60 employees) had 35\% of the resources, while small received $8 \%$ of the total funds. Sao Paulo state again was the more represented, with $44 \%$ of the exporters, and Rio de Grande do Sul exports accounted for an additional 29\% (MDIC, 2011).

Table 1 summarizes the main figures of the program between 2001 and 2011, allowing us to identify some of its virtues and problems. For instance, we can see the reach of the program is still very limited. Considering the financing instrument, the number of companies that benefited from the program has ranged between 300 and 450 approximately, in the period considered. As for the equalization instrument, the number is still lower, only benefiting less than 40 companies per year:

Table 1 - PROEX Summarized results 2001/2011

\begin{tabular}{|c|c|c|c|c|c|c|c|c|c|c|c|c|}
\hline Statistics & Instrument & 2001 & 2002 & 2003 & 2004 & 2005 & 2006 & 2007 & 2008 & 2009 & 2010 & 2011 \\
\hline Number & Proex Fin. & 294 & 308 & 341 & 409 & 452 & 337 & 358 & 359 & 400 & 371 & 312 \\
\hline firms & Proex Equal. & 216 & 152 & 53 & 44 & 32 & 32 & 35 & 37 & 35 & 31 & 34 \\
\hline Expenditures & Proex Fin. & 411 & 388 & 269 & 286 & 429 & 383 & 332 & 297 & 279 & 432 & 552 \\
\hline M US\$ & Proex Equal. & 477 & 115 & 303 & 153 & 232 & 192 & 184 & 180 & 158 & 118 & 185 \\
\hline Financed & Proex Fin. & 464 & 438 & 308 & 326 & 492 & 437 & 375 & 335 & 305 & 505 & 635 \\
\hline exports US\$ & Proex Equal. & 8193 & 2024 & 4064 & 2871 & 3041 & 3570 & 4039 & 4603 & 4000 & 3539 & 3499 \\
\hline Number & Proex Fin. & 958 & 1075 & 928 & 1142 & 1746 & 1391 & 1660 & 1366 & 1509 & 1478 & 1354 \\
\hline Operations & Proex Equal. & 4930 & 911 & 900 & 1217 & 1710 & 1716 & 2125 & 2900 & 2513 & 2657 & 2531 \\
\hline
\end{tabular}

Source: Bank of Brazil - Boletim PROEX 2001 to 2011.

In the period, the volume of money spent decreased from a maximum of US\$ 888 million in 2001 to US\$ 737 million in 2011, with approximately $74 \%$ allocated in the financing mechanism and the other $26 \%$ spent with equalization. The sharp decrease of the program's investment in the period can be explained by a combination of a decrease in the supply of funds, due to governmental budgetary constraints and an increasing participation of private funds, especially in the financing mechanism.

The number of deals that benefited from the equalization mechanism, which grew steadily since 2002 , reaching almost 3.000 deals in 2008. This result can be related to the significant volume of exports that were benefited with the equalization mechanism, reaching US $\$ 4.6$ billion in 2008, and diminishing in 2010/2011 with approximately US\$ 3.5 billion. 
These results reflect one important characteristic of the equalization mechanism, which is its leverage capacity. Since this mechanism would not require governmental funds for financing the principal of the exported volume, but only a small part of the operation represented by the rebate of interest rate, a relatively small volume of funds may benefit a significant volume of exports, as shown in table 1.

\subsection{PROEX PREVIOUS EVALUATIONS}

Previous attempts to evaluate the PROEX focused on the estimation of the overall program's impact on exports growth and diversification. Thus, using an econometric model, Moreira and Santos (2001) analyzed PROEX contribution to the growth of manufactured goods exports from 1991 to 2000. The results allowed the conclusion that PROEX, had a positive impact on the growth manufactured good exports.

Moreira et al (2006) extend the original model and developed an econometric model to measure PROEX impact from 1991 to 2005. They also found evidence that PROEX positively influenced the growth and diversification of Brazilian exports in the period considered. A few studies tried to identify the problems faced by firms as far as public and private financing are concerned (CNI, 2002; BLUMENSCHEIN; LEON, 2002; VEIGA; IGLESIAS, 2000). The main difficulties found were limited funds, excessive bureaucracy, information access, requirement of guarantees, and high costs.

As mentioned before, the market mechanisms were benefited by the reduction of funding costs. The progressive reduction of the country risk was responsible for a better quality credit to Brazilian companies. Measured by the Emerging Markets Bonds Index (EMBI) the Brazilian Country Risk decreased approximately $75 \%$ in the last 7 years. Regarding OECD criteria, Brazilian country risk fell from 6 to 3 in a 0 to 7 scale (OECD, 2007).

Nevertheless, Brazilian firms still are not able to compete in the same levels of developed countries firms, as far as funds availability and costs are concerned. The existence of market mechanisms does not imply that an official support program is not necessary. Yet, the recognition of important changes in the economic environment makes it necessary to think of improving and adapting the mechanisms and criteria adopted in the official programs.

To our knowledge, there is a lack of empirical studies dedicated to evaluate the effectiveness of the program (PROEX) in terms of reaching its specific objectives, as well as the governance and operational aspects of the program, although international initiatives are 
abundant. Nevertheless, Wilkinson and Brouthers (2000) state that the majority of the evaluations use qualitative perceptions of the quality and effectiveness of the export promotion programs instead of evaluations based on export data. Although the use of perceptions of the users of the programs is important, it has several limitations concerning the evaluation of the real impact of export promotion programs.

\section{AN EVALUATION MODEL}

Public managers face a continuous challenge: how to deal with an increasing demand for public policies and services that require growing public expenditure in an environment of limited capacity to increase governmental revenues (BARZELAY, 2001). Frequently the solution suggested for this dilemma is the implementation of comprehensive "Administrative Reforms" to redefine the role and size of the public sector, or a "Tax Reform" to improve financial strength of public finances. The problem with this "Big Reforms" approach is that they are technically controversial, politically complex and time consuming. Although the concern and commitment with "structural changes" should not be abandoned, public managers need to seek solutions to improve the efficiency, quality and governance of the public sector in the short term, which can be attained with a better performance management and evaluation.

Wholey (2012) states that Performance Management and Program Evaluation Systems have a synergic effect, because when performance data and indicators are collected in a regular basis a Program Evaluation becomes more feasible, less costly and more useful. In addition, the demand for such Evaluation Systems tend to be greater after agencies measure their programs, with the inputs, process, outputs and outcomes.

Therefore, the implementation of Evaluation Systems for the public programs and policies could allow for incremental changes in the quality of the public management (COSTA; CASTANHAR, 2003). In the specific case of evaluation of Export Promotion Program, the evaluation is essential for two main reasons. First, a well-designed evaluation program is likely to provide useful information to enhance the export promotion strategies and the knowledge about the benefits the policies may be able to increase firms' awareness and willingness to apply for the programs (BELOC; DIMAIO, 2011).

The evaluation system proposed comprises two different components. The first component is a panel of indicators that could be used by the program's managers to check to which extent the program's goals are being achieved in order to make recommendations for 
adjustments and improvements in the program. The second component is a methodology for setting the equalization rate for the loans benefited by the program.

This second component is the most important part of the evaluation system, since it can impact the governance of the program on several aspects, such as: defining the volume of the subsidies and costs of the program, improving the effectiveness, improving the transparency in the program management, while helping the country to comply with international regulations.

\subsection{THE PROGRAM LOGICAL FRAMEWORK AND INDICATORS}

Although the primarily focus of this study was to design a more effective methodology for the equalization subsidy, a few evaluation indicators were calculated for the program as a whole. The objective here is to provide information for the program managers, especially for the fiscal authorities in Brazil about the efficiency, effectiveness and impact of the program. The objectives of the Program were identified and described, using the Logical Framework instrument (Pffeifer, 2000; Mokate, 2002). The Logical Framework developed for the USAID as a tool to help conceptualize a project and analyze the assumptions used (Rosenberg \& Posner, 1979). The Logical Framework has proven to be a valuable tool for project design, implementation, monitoring, and evaluation. Program's Logical Framework is in Table 2:

Table 2: PROEX Logical Framework

\begin{tabular}{|c|c|c|}
\hline Objectives & Indicators & Sources \\
\hline $\begin{array}{l}\text { Increase exports } \\
\text { (1) }\end{array}$ & $\begin{array}{l}\text { Growth of exports } \\
\text { funded by the program }\end{array}$ & Bank of Brazil \\
\hline \multirow{2}{*}{$\begin{array}{l}\text { Improve funding } \\
\text { efectiveness } \\
\text { (2) }\end{array}$} & \begin{tabular}{|l|} 
Exported value for each \\
dollar expended
\end{tabular} & Bank of Brazil \\
\hline & $\begin{array}{l}\text { Share of exports } \\
\text { benefited by the } \\
\text { program on total } \\
\text { exports }\end{array}$ & $\begin{array}{l}\text { Bank of Brazil and Ministry of } \\
\text { Development, Industry and } \\
\text { International trade (MDIC) }\end{array}$ \\
\hline \multirow{2}{*}{$\begin{array}{l}\text { Increase the number of } \\
\text { exporting firms } \\
\text { (3) }\end{array}$} & $\begin{array}{l}\text { Growth of the number of } \\
\text { benefited firms }\end{array}$ & Bank of Brazil \\
\hline & \begin{tabular}{|l|} 
Average period of \\
PROEX utilization
\end{tabular} & $\begin{array}{l}\text { Treasury Department/Ministry } \\
\text { of Finance }\end{array}$ \\
\hline \multirow[t]{2}{*}{$\begin{array}{l}\text { Improve access of small } \\
\text { firms to export funding } \\
\text { (4) }\end{array}$} & $\begin{array}{l}\text { Exported value for each } \\
\text { dollar expended by firm } \\
\text { size }\end{array}$ & $\begin{array}{l}\text { Treasury Department/Ministry } \\
\text { of Finance }\end{array}$ \\
\hline & \begin{tabular}{|l|} 
Export structure by firm \\
size (PROEX x Total) \\
\end{tabular} & Bank of Brazil and MDIC \\
\hline $\begin{array}{l}\text { Export diversification } \\
\text { (5) }\end{array}$ & \begin{tabular}{|l|} 
Export structure by \\
industry sector (PROEX \\
x Total)
\end{tabular} & $\begin{array}{l}\text { Bank of Brazil, MDIC and } \\
\text { Central Bank }\end{array}$ \\
\hline
\end{tabular}


According to the Logical framework developed for the program, objectives 1 and 5 are composed by only one indicator, while objectives 2,3 and 4 have two indicators each. It's important to mention that the indicators were selected through an interactive process with program managers. We sought to compile a relevant group of indicators for continuous monitoring that also could be used as a management tool. Their definitions are presented below:

A) Growth of exports funded by the program - This indicator expresses the annual percentage increase or decrease of exports benefited by the program:

$$
G t=\left[\left(\frac{\text { Exports Funded by PROEX in } t}{\text { Exports funded by PROEX in } t-1}\right)-1\right] \times 100 . t=\text { year considered }
$$

If the indicator is positive it reflects a growth on PROEX financed exports, while negative results indicate a decreasing.

B) Exported value for each dollar expended - This indicator is the annual value of funded exports divided by the money expended in the program. It represents the value being exported for each dollar lent and is calculated as follows:

$$
B=\frac{\text { Exports funded by PROEX }(\$)}{\text { PROEX Expenditures }(\$)}
$$

C) Share of exports benefited by the program on total exports - This indicator expresses the representativeness of exports benefited by the PROEX over the total value of Brazilian exports. It is calculated as follows:

$$
C=\frac{\text { Exports Funded by PROEX }(\$)}{\text { Total Exports }(\$)}
$$

The closer to $100 \%$, the greater is the program impact. On the contrary, percentages close to $0 \%$ indicate a low impact.

D) Growth of the number of benefited firms - This is an indicator that represents the annually percentage change, positive or negative, of benefited firms by the program:

$$
D t=\left(\frac{\text { Number of Benefited firms in } t}{\text { Number of Benefited firms in } t-1}-1\right) \times 100 . t \text { is year considered }
$$

Therefore, positive results indicate an increase of benefited firms when compared to the previous year. A negative percentage expresses the decrease of benefited firms. 
E) Average period of PROEX utilization - This indicator expresses how many years, in average, firms used PROEX during a specific period of time. For the calculation of this indicator, all firms that used PROEX during the defined period are listed. For each year, a value is attributed to the firm: 1 if it used PROEX funds or 0 if it didn't use PROEX funds. Hence, the sum for each firm will be equal to the number of years that it had PROEX financing. The final indicator is the average result of all firms. The indicator was calculated for a time span of four years.

$$
E=\text { Average } \sum_{t=1}^{4} N t
$$

\section{Where $t=y e a r$ and $N=1$ if the company applied for $P R O E X, 0$ if not}

This indicator is a proxy of the "turnover" of firms in the program. A high value will indicate that, once the firm has access to the program, it will benefit from it continuously and a lower value will reflect a greater turnover of beneficiaries in the program.

F) Exported value for each dollar expended by firm size - This indicator compares the exports by firm size with the volume of money spent by the program in that particular firm size segment. This goal of this indicator is to evaluate whether funds efficiency might be related to firm size. It is calculated as follows:

$$
\begin{gathered}
F=\frac{\text { PROEX Exports by firms of Size } \mathbf{i}}{\text { Expenditures of the Program in firms of Size } \boldsymbol{i}}, \\
\text { Where } i=\text { firm size }- \text { small, medium or large }
\end{gathered}
$$

G) Export structure by firm size (PROEX $x$ Total) - This indicator compares a particular firm size segment share on the total exports benefited by PROEX, to this firm size segment share on total Brazilian exports. It is calculated as follows:

$$
\begin{gathered}
G i=\left(\frac{\text { PROEX Exports by firm size } i}{\text { PROEX Total Exports }}\right)-\left(\frac{\text { Total Exports by firm size } i}{\text { Total Exports }}\right) \\
\text { Where } i=\text { firm size }- \text { micro, small, medium or large }
\end{gathered}
$$

A positive sign means that firms of a specific size have greater representativeness on PROEX benefited exports compared with total exports of the program, while a negative sign means higher participation on total exports compared with total PROEX benefited exports. 
For instance, even though large firms have great representativeness on PROEXequalization, they have an even greater share of total exports. For smaller firms the sign is positive for both financing modes, proving that the program stimulates their access to exports.

\section{H) Export structure by sector (PROEX x Total)}

This indicator compares the share of the main sectors supported by PROEX to their performance regarding total Brazilian exports. The first part of the formula indicates each sector share on the program benefited exports, while the second part represents each sector share on total Brazilian exports value.

$$
H j=\text { Share of Proex Exports Sector } j(\%)-\text { Share Total Export Sector } j(\%)
$$

Therefore, a positive sign means that a specific sector has greater representativeness on PROEX exports than on Brazilian total exports, while a negative sign means greater representativeness on total exports.

Table 3 summarizes the values of the indicators defined for the 2003-2011 period, only for equalization of interest rate mechanism. Although we have calculated the indicators for both the direct funding and the equalization mechanisms, we opted for presenting and discussing only the performance of the equalization of interest rate mechanism, as the main objective of the research was to establish an optimal rate of subsidy for equalization program. We also took this decision based on the higher proportion of financed exports through equalization subsidy ( $85 \%$ ), and the limited space to present findings for both subsidies. 
Table 3 - PROEX Indicators 2003/2011

\begin{tabular}{|c|c|c|c|c|c|c|c|c|c|}
\hline & 2003 & 2004 & 2005 & 2006 & 2007 & 2008 & 2009 & 2010 & 2011 \\
\hline $\begin{array}{l}\text { A. Change of exports } \\
\text { generated through the } \\
\text { program }\end{array}$ & $101,2 \%$ & $29,3 \%$ & $5,9 \%$ & $17,4 \%$ & $13,2 \%$ & $13,9 \%$ & $13,1 \%$ & $11,5 \%$ & $-1,1 \%$ \\
\hline $\begin{array}{l}\text { B. Exported value for each } \\
\text { dollar expended }\end{array}$ & 13,42 & 18,79 & 13,14 & 18,61 & 21,98 & 25,51 & 25,33 & 29,91 & 18,88 \\
\hline $\begin{array}{l}\text { C. Share of exports generated } \\
\text { through the program on total } \\
\text { exports }\end{array}$ & $5,56 \%$ & $2,98 \%$ & $2,57 \%$ & $2,60 \%$ & $2,51 \%$ & $2,33 \%$ & $2,6 \%$ & $1,8 \%$ & $1,4 \%$ \\
\hline $\begin{array}{l}\text { D. Change in the number of } \\
\text { benefited firms }\end{array}$ & $-65,1 \%$ & $17,0 \%$ & $27,3 \%^{-}$ & $0,0 \%$ & $9,4 \%$ & $5,7 \%$ & $13,5 \%$ & $26,2 \%$ & $9,7 \%$ \\
\hline $\begin{array}{l}\text { E. Average period of PROEX } \\
\text { utilization }\end{array}$ & - & - & - & 2,24 & 2,5 & 2,27 & - & - & - \\
\hline \multicolumn{10}{|c|}{ F. Exported value for each dollar expended (according to firm size) } \\
\hline Large & 16,17 & 20,72 & 14,84 & 23,14 & 25,79 & 25,63 & 25,24 & 30,04 & 18,12 \\
\hline Small and Mediun & 1,70 & 6,93 & 5,38 & 8,04 & 11,14 & 24,59 & 26,03 & 29,54 & 17,69 \\
\hline \multicolumn{10}{|c|}{ G. Share by firm size (PROEX $x$ Total) } \\
\hline Large & $8,1 \%$ & $5,8 \%$ & $1,6 \%$ & $-4,4 \%$ & $-5,1 \%$ & $-4,8 \%$ & $-8,4 \%$ & $-3,6 \%$ & $1,3 \%$ \\
\hline Small and Mediun & $-8,0 \%$ & $-5,6 \%$ & $-1,4 \%$ & $4,5 \%$ & $5,3 \%$ & $4,9 \%$ & $8,4 \%$ & $3,6 \%$ & $-1,3 \%$ \\
\hline \multicolumn{10}{|c|}{ H. Share by firm sector (PROEX x Total) } \\
\hline Transports & $70,3 \%$ & $47,3 \%$ & $58,8 \%$ & $59,0 \%$ & $58,1 \%$ & $56,2 \%$ & $28,4 \%$ & $35,2 \%$ & $12,2 \%$ \\
\hline Machines and Equipments & $4,8 \%$ & $14,0 \%$ & $12,2 \%$ & $16,4 \%$ & $17,2 \%$ & $18,9 \%$ & $25,7 \%$ & $29,6 \%$ & $64,0 \%$ \\
\hline Services & $-10,5 \%$ & $-6,5 \%$ & $-5,9 \%$ & $-9,8 \%$ & $-9,0 \%$ & $-7,3 \%$ & $10,8 \%$ & $3,0 \%$ & $-6,3 \%$ \\
\hline
\end{tabular}

Sources: Bank of Brazil, MDIC, Treasury Department, Central Bank. Data not available: -

We can see that despite a negative growth in 2004, the volume of exports using the equalization mechanism grew at a significant rate in the period considered, reflecting the effectiveness of the instrument, as measured by indicator A, while in 2011 it reflected a small decrease. In addition, the productivity of the program experienced a continuous growth in the period, as shown by indicator B. The volume of exports generated by each dollar invested in the program almost doubled in the period, growing from 13.42 (2003) to 29.91 in 2010, with a decrease of the performance in 2011 with indicator B reaching 18.88. This result reflects the fact that in the last five years the volume of subsidy required had significantly decreased, also confirmed by indicator $\mathrm{C}$ that shows a decreasing dependency of the exports to the equalization rate benefit (ranging from 5.56 in 2003 to 1.4 in 2011).

One of the most disappointing results is the decrease of the number of benefited companies between 2003 and 2006. Although we found that this number resumed growth after 2006, it is still very low. The total number of benefited firms is only 346 in 2011, compared with 510 in 2001. As for the productivity (or elasticity) of the resources invested in the program to generate exports, the indicator $\mathrm{F}$ shows that the difference between large and small and medium companies is being narrowed in the period considered, almost converging to a similar value in 2008 and the subsequent years. 
Indicator G reflects one interesting result. We can see in table 3 that from 2003 to 2008 the representativeness of the large and small and medium companies in the PROEX as compared to the total exports experienced a radical change. Thus, up to 2005 the large companies were more represented in the PROEX than in the total export and that profile changed after that year. Conversely, the small and medium companies were under-represented in the PROEX program up to 2005 and became over-represented after 2005. This result may indicate that the program is benefiting an increasing proportion of small and medium companies, which is one of the program's goals.

As for the industry sector representation, the $\mathrm{H}$ indicator shows a significant and increasing concentration in the Transports and Machines and Equipment industries. When considering the average period of PROEX utilization, the indicator E shows that there is an apparent stability, with the an average period of utilization ranging from 2,24 to 2,5 years for the years with available data.

The panel of indicators shows that, for the period considered, the program achieved some very positive results, like the increasing productivity and the increasing access for small and medium companies, but also showed disappointing results, like the decreasing number of companies and a further sector concentration. This kind of results reinforces the necessity of extending the evaluation methodology, discussing the governance of the program, what will be developed in the following section.

\subsection{EQUALIZATION SETTING METHODOLOGY}

The second part of the evaluation model consists of a methodology for setting the equalization subsidy in the interest rate for exports operations, alternatively to the current practice of granting the maximum subsidy allowed by law. The model would seek, hence, to ensure an efficient and effective use of public resources, as well as the strategic aspects related to the use of the program to foster Brazilian exports and benefit a broader array of companies and sectors, especially small and medium companies. In addition, the model proposed was concerned with the legal aspects of the subsidies, in order to avoid future liabilities for Brazil.

The proposed model defines a set of measurable criteria for the PROEX operations, in order to calculate a more consistent equalization spread within the limits established by law. Nowadays, the spread is defined based on what we call "legal criteria". Current legislation establishes the products that may be benefited (Brazil, MDIC, 2002) as well as the maximum 
financing period allowed for each product. It also establishes maximum equalization percentages according to the financing period (Central Bank, 1999).

The model proposes to classify operations according to "commercial" and "strategic" criteria. Commercial criteria are related to the possibility of obtaining other than public financing sources. Strategic criteria are related to the objective of diversifying PROEX exports by offering Brazilian firms financing conditions comparable to international market.

For each criterion a classification scheme was created. Each financing operation is classified according to suggested criteria. The weighted sum of commercial criteria results in a factor to be deducted from the maximum equalization percentage. The sum of strategic criteria results in a factor of increasing the granted subsidy (reduction of the interest rate). The recommended equalization spread is calculated as follows:

\section{Recomended spread $=$ max spread allowed - commercial factor + strategic factor}

The maximum spread allowed is represented by legal criteria as defined by current legislation ${ }^{2}$. The commercial factor corresponds to commercial criteria and the strategic factor is equivalent to strategic criteria as defined as follows:

Table 4 - Commercial and strategic criteria

\begin{tabular}{|c|c|}
\hline Commercial criteria & Assumptions \\
\hline 1. Firm rating & $\begin{array}{l}\text { The greater the rating, the better the financing rates available to } \\
\text { the firm }\end{array}$ \\
\hline 2. Export value & $\begin{array}{l}\text { The larger the export value, the better the financing rates available } \\
\text { to the firm }\end{array}$ \\
\hline 3. Guarantees & $\begin{array}{l}\text { The better the guarantees offered, the better the financing rates } \\
\text { available to the firm }\end{array}$ \\
\hline 4. Importer country risk & $\begin{array}{l}\text { The better the country risk, the better the financing conditions } \\
\text { available }\end{array}$ \\
\hline Strategic criteria & Assumptions \\
\hline $\begin{array}{l}\text { 5. Funds distribution by } \\
\text { sector } \\
\text { 6. Funds distribution by firm }\end{array}$ & $\begin{array}{l}\text { Goal: do not concentrate more than } 50 \% \text { of funds in one sole } \\
\text { sector } \\
\text { Goal: do not concentrate more than } 40 \% \text { of funds in one sole firm }\end{array}$ \\
\hline
\end{tabular}

Regarding firm rating, the initial idea was to use a system from an internationally known rating firm. However, since many firms that use PROEX have foreign capital, it would not be possible to find a comparable scale among them. Therefore, an alternative rating was suggested based on available information regarding the subject: firm size, capital source (national/foreign) and rank at Brazilian exports.

\footnotetext{
${ }^{2}$ Two conditions are checked before the final spread. First the recommended spread cannot be greater than the maximum allowed; if that happens, the maximum spread allowed is considered, second, the resulting interest rate cannot be greater than CIRR; if that happens, the recommended spread will be the difference between interest conceded by the funder and CIRR.
} 
As far as guarantees are concerned, the proposal is to previously classify possible guarantees that a firm may offer in this kind of operation according to a rating scale. Country risk is the one defined by OECD - Country Risk Classification - that defines 8 risk levels for countries. A spreadsheet that calculates the recommended spread based on data informed about the operation, that is, legal, commercial and strategic criteria was then elaborated.

\subsubsection{Testing the methodology for setting operations}

Using information provided by the program manager, simulations for specific operations and for one whole month (FEBRUARY, 2006) were made until the actual proposed model was achieved. For instance, one operation submitted to the model passed the first verification but had its final rate lower than CIRR, forcing a reduction on the recommended spread.

An aggregated simulation was also made, considering all operations from February, 2006. Information about financing period, export value and importer country of each operation were identified. Information about firm rating and funds concentration on sector and firm were approximated. Facing the lack of information about guarantees, they were defined according to firm size.

A sample operation with the following characteristics was used for simulation of the methodology to calculate the recommended spreads:

Table 5: Sample Characteristics of Operation Parameters

\begin{tabular}{ll}
\hline Characteristics of the operation & \\
\hline Firm Name & XYZ \\
Exports value & USD 4.108.747,83 \\
Number of payments & 10 \\
Importer Country & Mexico \\
Size of the Company & Big \\
Position on Exports Ranking & $11^{\text {th }}$ \\
Warranty Classification & $\mathrm{A}$ \\
\hline
\end{tabular}

Considering the characteristics presented on table 5, the maximum spread is $1.5 \%$ $(\mathrm{L}=1.5)$. The next step is the calculation of the commercial reductor, based on three factors: company rating, warranty classification and risk of importer country. The third step is the calculation of the strategic factor, according to the concentration of resources for the company and the sector where it operates. After all parameters are calculated, the data is inputted in a custom made spreadsheet where the new recommended spread is calculated automatically.

The last step involves the validation of the spread calculated. For the validation process, the interest available from the financer must be informed. If the spread recommended is 
superior to the maximum allowed equalization percentage, the legal maximum equalization is used, if lower the recommended spread is considered validated.

For use of the model, the CIRR must be updated monthly, considered a second validation. If the rate for the exporter is lower than CIRR, then the CIRR is used (spread is difference between interest rate from the financer and the CIRR). If the resulting rate is higher than the CIRR, then the calculated rate is validated and the recommended spread is validated.

Data from 142 exporting companies were processed through the mentioned spreadsheet. Of those, 134 were considered big companies, and 8 medium sized. The foreign firms were most frequent (104), with 38 companies with national capital. The number of payments varied from 2 to 20 (avg=9.47). The average interest rate available from financing was $6.97 \%$ ( $\min =6.84, \max =7.34)$. Country risk ranged from 0 to 7 (OECD Risk Classification), while the most frequent value (mode) was 0 .

Warranties for the companies were mostly graded A ( $n=89)$, followed by BBB $(n=28)$, AAA $(n=14), A A(n=6), C C(n=6), B B(n=1)$ and $B(n=1)$.

Total equalization cost was calculated multiplying the spread by the financed value. The previous value was 10.168.674 US\$. Using the new methodology the resulting cost was almost 30\% lower than the cost calculated with real spreads (new calculation totaled 7.199.247 US\$). The new recommended spreads averaged $0.82(\min =0.25, \max =1.74)$.

\section{CONCLUSIONS AND RECOMMENDATIONS}

The implementation of suggested indicators as well as their continuous monitoring will make it possible to verify public policy reach, becoming an important management tool. As expected, the simulations realized to test the suggested equalization model produced satisfying results. Nevertheless, the established criteria were based only on research and historical data of operations. Besides, the cause-effect relations among variables were based on theoretical suppositions, and not on manipulated variables. To establish causality, an experimental design must be used, since the data used was cross-sectional, the results must be interpreted with care.

Therefore, further testing the relations as well as validating the defined criteria with program managers and with other agents involved such as banks and firms will produce more accurate results. Also, the impact analysis of spread reduction over Brazilian firms financing rates may statistically indicate a need to reduce the equalization spread. Therefore, a few recommendations are listed to improving the model: 
1) Econometric model to provide empirical validation to the equalization setting methodology. It is necessary to test the relations between the criteria used and their impact on financing costs. Besides, once the relations are tested, the weight of each criterion should be calculated in the system as a whole.

2) Impact evaluation of country risk reduction over Brazilian firms' financing rates for exports (since 1999) in order to update the maximum spreads defined by law.

3) Interviews among firms that use or have used PROEX as well as among those that have exports as an important activity but never used it. It is necessary to identify the reasons of a possible lack of demand.

Despite eventual limitations, the study sheds light to other important issues. For instance, some proposals related to the program are being discussed, such as: creation of a scroll account fund to reduce the dependence of the incentives on the Governmental budget, and incentives for stimulating firm interest for the program and financial intermediaries' willingness to offer the program as a financing product.

It is worth to mention the importance of transparency of information to avoid future discussions and litigations at WTO. Further, to avoid disputes it is not only the minimum financing rate that matters, but also the whole "financial package" offered with public support including guarantees, maturity, etc.

The importance of a continuous evaluation of the program goals accomplishment is more than relevant. The results of the evaluation could also help the Government to ensure consistency between the goals of the program with other aspects of the institutional environment as well as other public policies and programs. This could lead to improvements in the effectiveness of the program and in the public management in general.

\section{REFERENCES}

BAER, W. The Brazilian boom 1968-72: an explanation and interpretation. World Development, v. 7, n. 8, ago. 1973.

BARZELAY, M. The new public management: improving research and policy dialogue. California: Univ. of California Press, 2001. v. 3.

BCB. Banco Central do Brasil. 2012. Disponível em: <www.bcb.gov.br>.

. Boletim Seção Balanço de Pagamentos: BCB Boletim/BP. 2013. 
BELLOC, M., DI MAIO, M. Survey of the literature on successful strategies and practices for export promotion by developing countries. International Growth Centre, Working Paper No. 11/0248, 2011.

BERNARD, A. B.; JENSEN, J.B. Exporters, jobs, and wages in U.S. manufacturing: 19761987. Brookings Papers on Economic Activity. Microeconomics, p. 67-119, 1995.

BLOMSTRÖM, M.; KOKKO, A. Multinational corporations and spillovers. Journal of Economic Surveys, v. 12, n. 2, 1998.

BLUMENSCHEIN, F.; LEON, F. L. L. Uma análise do desempenho e da segmentação do sistema de crédito à exportação no Brasil. In: BNDES. O desafio das exportações. BNDES 2002.

BRAZIL. Ministério do Desenvolvimento, Indústria e Comércio Exterior. Portaria MDIC no 58, 10 de Abril, 2002.

CASSIMAN, B.; GOLOVKO,E.; MARTÍNEZ-ROS, E. Innovation, exports and productivity. International Journal of Industrial Organization, v. 28, p. 372-376, 2010.

CENTRAL BANK. Circular no 2.881. 19 nov. 1999.

CNI. Confederação Nacional da Indústria. Os problemas da empresa exportadora brasileira. Brasília, 2002.

FEDER, G. On exports and economic growth. Journal of Development Economics, v. 12, n. 1-2, p. 59-73, 1982.

FEINBERG, R. E. Subsidizing success: the export-import bank in the U.S. economy. Cambridge: Cambridge University Press, 1982.

HARRISON, A.; RODRÍGUEZ-CLARE, A. Trade, foreign investment, and industrial policy for developing countries. NBER Working Papers, 15261, 2009.

HARRIES, H. Financing the Future. KFW: the German bank with a public mission. Frankfurt am Main: Verlag Fritz Knapp GmbH, 1998.

KAVOUSI, R. M. Export expansion and economic growth: further empirical evidence. Journal of Development Economics, v. 14, p. 241-250, 1984.

LUSTOSA DA COSTA, F.; CASTANHAR, J. C. Avaliação de programas públicos: desafios conceituais e metodológicos. Revista de Administração Pública, Rio de Janeiro, FGV, v. 37, n. 5, p. 969-92, set/out. 2003.

MDIC. Ministerio do Desenvolvimento Industria e Comercio Exterior. Boletim PROEX. 2011.

MELITZ, M. J. International trade and heterogeneous firms. In: DURLAUF, S. N.; BLUME, L. E. (Eds.). The New Palgrave Dictionary of Economics. 2. Ed. London: McMillan, 2008.

MOKATE, K. M. Convirtiendo el "Monstruo" en Aliado: la evaluación como herramienta de la gerencia social. Revista do Serviço Público, ano 53, n. 1, jan./mar. 2002. 
MOREIRA, S. V.; SANTOS, A. F. Políticas públicas de exportação: o caso do PROEX. Textos para Discussão - IPEA, v. 836, p. 45, 2001.

MOREIRA, S. V.; TOMICH, F.; RODRIGUES, M. G. PROEX e BNDES-EXIM:

Construindo o Futuro. Textos para Discussão - IPEA, v. 1156, p. 33, 2006.

NEVEN, D.; SEABRIGHT, P. European industrial policy: the airbus case. In: Economic Policy. Norwich, 1995.

OECD. Export Credit Financing Systems: in OECD member countries and non-members economies. 2005.

Country risk classifications of the participants to the arrangement on officially supported exports. Oct. 2007.

PFEIFFER, P. O quadro lógico: um método para planejar e gerenciar mudanças. Revista do Serviço Público, ano 51, n. 1, jan./mar. 2000.

PREBISCH, R. O desenvolvimento da América Latina e seus principais problemas. Revista Brasileira de Economia, ano 3, n. 3, set. 1949.

RICHARDSON, J. D; RINDAL, K. Why exports matter: more! Washington, DC: the Institute for International Economics and the Manufacturing Institute, 1996.

ROSENBERG, L. J.; POSNER, L. D. The logical framework: a manager's guide to a scientific approach to design and evaluation. Washington, DC: Practical Concepts, 1979.

SECRETARIA DE COMERCIO E SERVICOS. Serviços: panorama do comércio internacional. 2012. Disponível em:

<http://www.desenvolvimento.gov.br/arquivos/dwnl_1347547603.pdf>.

SCHANK, T.; SCHNABEL, C.; WAGNER, J. Do exporters really pay higher wages? First evidence from German linked employer-employee data. Journal of International Economics, v. 72, n. 1, p. 52-72, 2007.

TAVARES, M. C. Auge e declínio do processo de substituição de importações no Brasil. In: Da substituição de importações ao capitalismo financeiro: ensaios sobre a economia brasileira. 10. ed. Rio de Janeiro: Zahar Editores, 1963.

TAYLOR, C.; HENISZ, W. U.S. manufacturers in global marketplace. Report 1058, the Conference Board, 1994.

TYLER, W. G. Growth and export expansion in developing countries: some empirical evidence. Journal of Development Economics, v. 9, p. 121-130, 1981.

UN, United Nations. United Nations e-government survey 2012: E-Government for the People. 2012. Disponível em: 〈http://unpan3.un.org/egovkb/global_reports/12report.htm>.

VEIGA, P. M.; IGLESIAS, R. A política de financiamento à exportação no Brasil. In: REDIPEA/BID. Aspectos estratégicos da política comercial brasileira. Oct. 2000. 
;. Políticas de incentivo às exportações no Brasil entre 1964 e 2002: resenha de estudos selecionados. Temas de Economia Internacional - 02. Brasília: Ministério da Fazenda, Secretaria de Assuntos Internacionais, 2003.

WILKINSON,T. J.; BROUTHERS, L. E. An evaluation of state sponsored promotion programs. Journal of Business Research, 2000.

WHOLEY, J. S. Using evaluation to improve program performance and results. In: MARVIN, C. A. (Ed.). Evaluation roots: a wider perspective of theorists' views and influences. 2. Ed. Cambridge: SAGE Publications, 2012. 